GLOBAL MEDICAL ETHICS

\title{
Making regulations and drawing up legislation in Islamic countries under conditions of uncertainty, with special reference to embryonic stem cell research
}

\author{
S Aksoy
}

J Med Ethics 2005;31:399-403. doi: 10.1136/jme.2003.005827

Correspondence to: Dr S Aksoy, Harran University, Faculty of Medicine, Department of Medical Ethics and History of Medicine, Morfoloii Binasi, 63300 Sanliurfa, Turkey;

saksoy@harran.edu.tr

Received 17 July 2003 In revised form 3 June 2004 Accepted for publication 30 July 2004
Stem cell research is a newly emerging technology that promises a wide variety of benefits for humanity. It has, however, also caused much ethical, legal, and theological debate. While some forms of its application were prohibited in the beginning, they have now started to be used in many countries. This fact obliges us to discuss the regulation of stem cell research at national and international level. It is obvious that in order to make regulations and to draw up legislation at national or international levels it helps to know the perspectives of different cultures and faith traditions. In this article the issue is explored from an Islamic perspective. Firstly, some basic information is given about Islam to explain how laws are drawn up and regulations made in this tradition. Secondly, the principles on which the laws and regulations are based are applied to stem cell research, and finally the permitted and prohibited methods of stem cell research are described. The discussions throughout the paper demonstrate that while some ethicists argue that stem cell research is unethical in the Islamic tradition, tradition permits it as long as such research is aimed at improving human health.
S cience continues to push the boundaries as it pursues its goal of knowing the unknowable and doing the undoable. Innovations in the medical sciences in recent decades have caused lay people as well as moralists to review their age old values. Reports published in November 1998 by independent teams of US scientists provide two more examples of this. ${ }^{1}$ The researchers reported that they had succeeded in isolating and culturing stem cells obtained from human embryos and fetuses. ${ }^{2}$ These developments required that the legal, ethical, and scientific issues associated with this research be critically addressed and articulated.

Stem cells are the cells from which all 210 different kinds of tissue in the human body originate. Because many diseases result from the death or dysfunction of a single cell type, scientists believe that the introduction of healthy cells of this type into a patient may restore lost or compromised function.

While it is in no way to be disputed that the ability to treat or heal suffering people is a great good, it must also be recognised that not all methods of achieving a desired good are necessarily morally justifiable. This newly emerging technology has caused a great deal of ethical, legal, and theological discussion and debate. ${ }^{3}$ Since, however, this technique has started to be used in many countries it needs to be regulated nationally and internationally in one way or another. When making regulations and drawing up legislation at either national or international level it helps to know the perspectives of different cultures and faith traditions. This article explores the issue from an Islamic perspective. Firstly, some basic information will be given about Islam to explain how laws are drawn up and regulations made in this tradition. Secondly the principles upon which the laws and regulations are based will be applied to stem cell research, and finally the permitted and prohibited methods of stem cell research will be described.

\section{THE ISLAMIC RULES FOR MAKING REGULATIONS AND DRAWING UP LEGISLATION}

First of all it may be of benefit to define some concepts. "Islam" literally means submission, submission to the will of
Allah, to the will of God. Islam regulates every aspects of a Muslim individual's life, from marriage to eating habits, from worshipping to leisure time. Therefore it is not surprising that the legal system of an Islamic country is based on Islamic rules. All these regulations are defined by one word: "Shari'ah". The Shari'ah deals with ideology and faith, behaviour and manners, and everyday practical matters. The norms and assumptions that have characterised belief and action in Islam have two foundational sources. The primary source is the Qur'an, revealed by God to the Prophet Muhammad (d 632). The other is the Prophet's actions and precepts, collectively called the Sunnah. Muslims regard the Qur'an as the ultimate and final disclosure in a series of revelations to humankind from God, and the Sunnah as the description of the life and example of the Prophet Muhammad.

The Sunnah confirmed the rulings of the Qur'an, detailed some of the concepts, laws, and rulings on practical matters, which are briefly stated in the Qur'an, and outlined some rules regarding matters not explicitly stated in the Qur'an. The four Sunni schools of thought, Hanafi, Maliki, Shafi'I, and Hanbali, are identical in approximately $75 \%$ of their legal conclusions. Variances in the remaining questions are traceable to methodological differences in understanding or authenticating the primary textual evidence. Differing viewpoints sometimes exist even within a single school of thought.

The legal material of the Qur'an is contained in about 500 verses (out of 4444), according to various estimates. These rulings were revealed with the aims; of abolishing objectionable customs such as infanticide, usury, gambling, and unlimited polygamy; of prescribing penalties for misdeeds, and of laying down rules for core worshipping activities such as prayer, fasting, charity, and pilgrimage. Other legal verses deal with: oaths; marriage; divorce; dowries; maintenance and custody of children; fostering; paternity; inheritance; bequests; relations between rich and poor; justice; evidence; consultation, and war and peace.

Abbreviations: ESC, embryonic stem cell; IVF, in vitro fertilisation 
The term "Sunnah" was introduced into legal theory toward the end of the 7th century. The activities and commands of the Prophet fall into different legal categories. Some are legally binding. These are based on the actions, behaviour, and instructions of the Prophet as the head of state and as judge, like-for example, prayers five times a day. Those that are not legally binding arise from the natural everyday activities of the Prophet such as the manner in which he ate, slept, and dressed, and other activities which do not form a part of Shariah. These are described as the habits of the Prophet.

Certain activities may fall in between the two. Only competent scholars can distinguish between the two in such areas. Sunnah-for example, has to do with technical knowledge such as medicine, while agriculture is not part of Shariah according to most scholars.

If one cannot find a text from the Qur'an or Sunnah with a bearing on the matter in hand, then one turns to a third source, "ijma" (general agreement) ${ }^{4}$ Ijma is considered as the third source of Islamic jurisprudence after the Qur'an and the Sunnah. The classical definition of Ijma is unequivocal on the point that the universal consensus of the scholars of the Muslim community as a whole constitutes conclusive ijma. Only such ijma were considered binding by early scholars. However, universal ijma are very few indeed. As the evidence shows, it is extremely difficult to prove ijma in relation to specific issues, particularly in the case of issues open to ijtihad (interpretation of one or a few scholars). Ijma, as classically defined, is, however, no longer possible in modern times (because of the vast number of scholars spread all over the world). We can have only local ijma, which is useful in law making through parliament but they cannot be (by definition) binding forever. Qiyas (analogical deduction), istihsan (juristic preference), and maslahah (benefit or interest) are more important today and will remain so in the future.

"Istihsan" literally means to deem something preferable. In its juristic sense, istihsan is a method of exercising personal opinion in order to avoid any rigidity and unfairness that might result from literal application of the law. Istihsan is an important branch of ijtihad, and has played a prominent role in the adaptation of Islamic law to the changing needs of society. Istihsan authorises departure from an established precedent in favour of a different ruling for a stronger reason. A very famous hadith (prophetic saying): "La darara wa la dirara fil Islam" (No harm shall be inflicted or tolerated in Islam) has been quoted in support of istihsan.

Another way of making regulations and drawing up laws in Islamic countries is by using the concept of maslahah. Maslahah literally means benefit or interest. When qualified as maslahahmursalah it refers to unrestricted public interest. In the opinion of Al-Ghazali maslahah consists of considerations which secure a benefit or prevent a harm. ${ }^{5}$ Protection of life, religion, intellect, lineage, and property is maslahah.

As I have tried to show throughout the paper so far, the sources of figh (jurisprudence in the Islamic tradition) - that is, Qur'an, Sunnah, ijma, qiyas, istihsan, and maslaha are not equal categories: there is a rank order in which these sources are used. In the process of establishing a legal or ethical position, if the Qur'an or Sunnah has a clear commandment then the other sources do not need to be used. Ijma, qiyas, etc are supplemental sources.

\section{STEM CELLS FROM DIFFERENT SOURCES AND THEIR REGULATION IN TERMS OF ISLAMIC ETHICS/LAW}

Let us look at the issue of stem cell research and apply these rules to such research. Today, human stem cells can be derived from the following sources: 1) human fetal tissues following abortions; 2) human embryos that are created by in vitro fertilisation (IVF); 3 ) adult stem cells, which are obtained from bone marrow, skin, liver, pancreas, brain etc, and 4) cloned human embryos.

It is now readily accepted that stem cell research has the potential greatly to benefit many people. It is difficult to estimate how many people might benefit from the products of stem cell research should it be permitted and prove fruitful. It might eventually enable us to grow tailormade human organs. In addition to tailormade organs or parts of organs, such as the liver-for example, it may be possible to use embryonic stem cells (ESCs) to colonise damaged parts of the body, including the brain, and to promote the repair and regrowth of damaged tissue. ${ }^{6}$

Although the use of adult stem cells has great potential ${ }^{7}$ for the future raises very few moral objections, the current sources of stem cells for experimentation are mostly embryonic and fetal material. Therefore the moral status of embryo is at the heart of the discussion. ${ }^{8}$

Although there are some "developmental" ethical positions that give the embryo different rights at different phases of development ${ }^{910}$ there are, generally speaking two opposite poles of opinion. One pole sees the early embryo as a ball of cells and nothing more, ${ }^{11}$ and maintains that since it is not fully formed and would not survive outside of the womb, research on human embryos is permissible. This position also holds that early embryos may also be used routinely as a source of stem cells. Proponents of this position say that the potential medical consequences wholly justify the action, and some indeed claim ESC research is a duty of humanity. The position taken at the other pole is that the embryo has the status of a human being from conception onwards, ${ }^{12}$ and that research or use that is not for the benefit of that particular embryo should be forbidden. This view rejects any technology that involves creating dispensable embryos, including the provision of replacement cells. The embryo is seen as a human subject which would be destroyed in the research. Like many other religions, Islam has its own perspective on the status of embryo. ${ }^{13}$ Islam considers human life as valuable and as deserving of protection from conception onwards. Islam does, however, acknowledge some form of dualism - that is, it recognises that the body and soul subsist together, and meet to form a "full human person". The creation of human individuality, and fetal development are referred to in several dozen verses of the Qur'an in various contexts, ${ }^{14-29}$ and also in hadith. In particular, two verses and two hadith are worth mentioning here as they help one to understand the Islamic view of the time of ensoulment and what the status of personhood entails.

The first verse is:

He Who created all things in the best way and He began the creation of man from clay. Then made his progeny from a quintessence of despised liquid. Then He created him in due proportion, and breathed into him of His spirit. And He gave you (the faculties of) hearing and sight and hearts. Little thanks do ye give!" (The Noble Qur'an, ${ }^{14} \mathrm{pp}$ 7-9)

This verse clearly reports that the first human is "shaped" (in due proportion), then he is "ensouled", and finally the faculties of hearing and sight and hearts are formed. This verse informs us about the "stage" of ensoulment during the intrauterine life.

The second is:

And indeed We created man from a quintessence of clay. Then We placed him as a small quantity of liquid (nutfa) in a safe lodging firmly established. Then We have fashioned the nutfa into something which clings ('alaqa), then We 
made 'alaqa into a chewed lump of flesh (mudgha) and We made out of that chewed lump of flesh into bones, and clothed the bones with flesh. And then We brought it forth as another creation. So blessed be God, the Best to create" (The Noble Qur'an, ${ }^{15}$ pp 13-14).

This verse is not as open as the first one. It is possible to make different comments regarding the stages of physical developments mentioned in this verse. I do not, however, wish to do that here since it is rather beside the point I am exploring here, which is the time of these physical developments, which I shall examine later.

The role of hadith in Islamic teaching is to help us better understand and interpret the verses of the Qur'an, since Prophet Muhammad is the ultimate interpreter of the Qur'an. The Prophet Muhammad was not only a religious or political leader for his nation but also a guide who would teach Muslims how to understand qur'anic verses. He was reported to have said two hadiths, that I shall quote later, which will help us greatly to better understand qur'anic verses above, especially as they relate to the physical development of the embryo and the time of ensoulment.

The Prophet Muhammad said;

Verily your creation is on this wise. The constituents of one of you are collected for forty days in his mother's womb; it becomes something that clings ('alaqa) in the same (period) (mithla dhalik), then it becomes a chewed lump of flesh (mudgha) in the same (period) (mithla dhalik). And the angel is sent to him with instructions concerning four things, so the angel writes down his provision (sustenance), his death, his deeds, and whether he will be wretched or fortunate. Then the soul is breathed into him. ${ }^{30}$

And;

After the zygote (nutfa) has been established in the womb for forty or forty five nights, the angel comes and says: "My Lord, will he be wretched or fortunate?" And both these things would be written. Then the angel says: "My Lord, would he be male or female?" And both these things are written. And his deeds and actions, his death, his livelihood; these are also recorded. Then his document of destiny is rolled and there is no addition to and subtraction from it. ${ }^{30}$

There are different versions (narrations) of both hadiths with very minor differences. The first hadith is reported only by Abdullah b Mes'ud, but the second one is reported by Hudhayfa b Asid and by some other "companions", or sahabah-close friends, of the Prophet Muhammad. Many hadith scholars, referring to the first hadith only, and understanding the expression mithla dhalik as "time equal to this period" rather than "in the same period", have suggested that the angel comes to the prenate and breathes in the soul 120 days after conception. ${ }^{31}$ Some ancient scholars, ${ }^{32}$ as well as some contemporary researchers, ${ }^{33}{ }^{34}$ have disagreed about this interpretation, and concluded from both hadiths that, if one understands the expression mithla dhalik to mean "in the same period", then the completion of certain physical forms and ensoulment take place after the 40th day of conception. As I have discussed elsewhere, to interpret the expression mithla dhalik to mean "in the same period" is more accurate in this context from both an embryological and a theological perspective. ${ }^{35}$

If it is accepted that ensoulment takes place at 120 days, the embryo should look like a nutfa (a drop of liquid: the zygote) between days 0 and 40; it should be something like alaga (something which clings: the implantation stage) between days 40 and 80 , and it should be similar to mudgha (a chewed lump of flesh: the occurrence of somites- the appearance of the primitive streak) between days 80 and 120 . As we know from modern embryology these stages occur well before these times. ${ }^{36}$ It can be understood from these verses and hadith that, in order to receive the soul, that means to be a full human individual person, a prenate must pass through the various stages of conception: zygote (nutfa); implantation ('alaqa); formation of somites - the appearance of the primitive streak-(mudgha), and the beginning of the formation of bone and muscles. According to the embryological information given above ensoulment cannot take place before seven weeks after conception, since these embryological stages are not completed before this time. ${ }^{36}$

When the second hadith I have quoted here is examined, it appears that they both express very clearly that the angel comes-obviously to give the soul-after the nutfa (zygote) has been established in the womb for 40 or 45 days-or nights. Since the implantation process is completed within nine to ten days of conception, ensoulment takes place sometime between 49 and 55 days after conception.

From the information derived from these verses and hadiths and on the basis of current embryological knowledge we can say that the soul meets with body at the beginning of eight weeks' gestation, around day 50, and forms a "full human person". ${ }^{37}$ Therefore, according to many Muslim scholars, terminating the life of an embryo before ensoulment is regarded as something to be disliked (makruh), while it is considered as forbidden (haram), after this stage. ${ }^{38}$ This conclusion is particularly important for discussions concerning abortion, cloning, and stem cells.

If we evaluate these findings in terms of stem cell research, there is no problem with using adult stem cell as long as this does not harm the donor. Islam encourages seeking remedies and treatments. The Prophet Muhammad is reported to have said: "There is a cure for every illness, though we may not know it yet". ${ }^{39}$ Therefore, the development of new treatment methods and the use of such new methods, proven successful, is strongly recommended.

Indeed, in the full sense of the Arabic terms used in the relevant Prophetic sayings, the seeking of treatment is commanded rather than merely commended. ${ }^{40}$ There are different views, however, as to the limits on research aimed at finding new treatments. One is the acceptability or not of treatment using haram (forbidden) ways. Islamic scholars have referred to the hadith and Sunna to resolve this issue. The Prophet Muhammad is reported to have said: "God has sent both the disease and cure, and there is a cure for every illness, [therefore] be treated [but] do not to be treated with haram". ${ }^{4}$ Since using adult stem cells for treatment is not, in principle, different from organ transplantation it is acceptable and advisable from an Islamic perspective.

As far as the use of fetal stem cells is concerned, the age and the origin of the fetus should be known. If the fetus is the product of a spontaneous abortion (or miscarriage) there is no problem using it, since it will be disposed of anyway. If its age is more than $\mathbf{5 0}$ days, since the abortion is forbidden (haram) after this stage, there is doubt about the appropriateness of its usage. As the hadith recommends that a person is not to be treated with forbidden (haram) substances it can be argued that it is not permissible to use fetal stem cells. It should, however, be kept in mind that in this case, what is forbidden is the "action" not the "substance". Islam considers some substances as "clean" or "pure" (tahir) and some as "impure", such as pig and its products, and alcohol, due to its nature. The "substance", which is the fetus in this case, is tahir (clean, pure) whether it is before or after 50 days 
of development. Therefore, provided that the abortion is not initiated for the purpose of obtaining fetal stem cells and the fetuses will be disposed of anyway, by using one of the most frequently employed maxims among Islamic legal scholars, "Al-darûrât tubîh al-mahzûrât" (necessities render the prohibited permitted), ${ }^{31}$ it is possible to say that the fetal stem cell can be used for therapy. Sachedina, a Muslim theologian who has reported on stem cell research to the National Bioethics Advisory Commission in the US, said "research on stem cells made possible by biotechnical intervention is regarded as an act of faith in the ultimate will of God as the Giver of all life, as long as such an intervention is undertaken with the purpose of improving human health". ${ }^{42}$

In the matter of using embryonic stem cells we need to know how the embryos are produced. Since the embryos used in embryonic stem cell research are mostly the spare embryos from in vitro fertilisation (IVF) treatments it is of benefit to know the Islamic approach to IVF treatment, which is that it is permitted as long as it is performed between a living husband and wife with their consent. Producing spare embryos and storing them in a freezer for future use is not, however, legitimate. ${ }^{43}$ The reason for this prohibition, as will be explained later, is the possibility of misuse of these embryos.

According to the Islamic Fiqh Association (IFA) in Jeddah in association with the Medical Fiqh meeting in Kuwait in the year 2000, if there are excess embryos in any shape or form, they should be left without medical intervention to end their life naturally. ${ }^{44}$ It is not possible, however, to accept this view since this argument is based on the fear of the "misuse" of embryos rather than on theological or philosophical reasoning. It is apparent from the argument that allowing the embryo to die on its own is not refuted because this constitutes killing the potential human being. Some argue that the use of embryonic stem cells constitutes killing the unused embryo by means of taking the cells. However, allowing the embryo to die also constitutes killing the embryo, but this time by means of not taking any steps to save the potential human being.

To better understand my objection to the decision of the IFA the reader should bear in mind that expert opinion is always carefully considered and weighed in the Islamic tradition. When an expert-that is, in this case a physician, talks in a conscientious manner about a particular subject, the people of the religious community usually listen to what he has to say. ${ }^{45}$ Therefore if a responsible physician suggests that to create spare embryos is necessary for the success of IVF treatment then this suggestion can be acted upon. It is safe to say, however, that doctors should create the minimum number of required embryos, in order to avoid the unnecessary wasting of human lives. In addition, the couple should also be informed that, if everything goes well, they should consent to all the embryos being implanted. If, despite all these precautions, there are spare embryos which will be destroyed, these embryos can be used in stem cell research, since they have not yet been ensouled, and are therefore not full human persons. This suggestion was also supported by Basalamah, who argued that: "At the point when a fertilised egg has reached stage eight and has divided into 32 cells only, no limbs or organs are yet formed. Therefore, at least at present, it is not possible to use surplus eggs for organ transplantation, although it is possible to use some of their cells. Transplanting such cells is far better than destroying them." ${ }^{\prime 46}$

Another way of obtaining stem cells is, as by so called "therapeutic cloning". ${ }^{47}$ Therapeutic cloning (or biomedical cloning) is a procedure whose initial stages are identical to adult DNA cloning. The stem cells are removed from the embryo with the intention, however, of producing tissue or a whole organ for transplant back into the person who supplied the DNA. The pre-embryo dies in the process. The goal of therapeutic cloning is to produce a healthy copy of a sick person's tissue or organ for transplant. This technique could well prove to be vastly superior to relying on organ transplants from other people. The supply would be unlimited, so there would be no waiting lists. The tissue or organ would have the sick person's original DNA; the patient would not have to take immunosuppressant drugs for the rest of their life, as is now required after transplants. There would not be any danger of organ rejection. The European Council Ethical Advisory Group, however, had reservations and saw therapeutic cloning as a premature development. ${ }^{48}$

There are many Muslim scholars of different legal traditions who argue that in the Islamic tradition therapeutic uses of cloning and any research to further that goal will receive the endorsement of the major legal schools. In the case of cloning specifically for the purposes of relieving human disease, there is no ethical impediment to stop any such research which on the scale of probable benefit outweighs possible harm. Some may question how, if Islam forbids deliberately creating an embryo by IVF to be destroyed for stem cells, it can then consider it to be permissible to deliberately create an embryo by cloning and then destroy it for stem cells. It must be kept in mind that there is no single binding view in the Muslim tradition on biotechnological issues, and this is especially true of newly emerging biotechnological issues. Although the majority of Muslim scholars may agree on a particular decision, it is still possible to put forward an alternative view and to follow this stance in practice. Since all kinds of actions are in principle permissible in Islam as long as they are not categorically prohibited, creating embryos either by IVF or by cloning should be permissible as long as it is with the purpose of improving human health. In 1997 a conference was organised in Casablanca by The Islamic Fiqh Council. A consensus was reached "that cloning does not bring into question any Islamic belief in any way. Allah is the Creator of the universe but He has established the system of cause and effect in this world. Sowing a seed in the ground is the cause but only Allah produces the effect from it in the form of a plant. Similarly cloning is a cause and only through Allah's Will can it produce the effect. Just as the person sowing the seed is not the creator of the resulting plant, so the cloning technician is not the creator of the resulting animal. Allah alone is the Creator and all creation takes place solely through His Will." 49

\section{CONCLUSION}

Science and technology continue to push the boundaries in order to pursue their goal of knowing the unknowable and doing the undoable. As logic dictates, man cannot do the things that are intrinsically undoable, and cannot know the things which are intrinsically unknowable. Therefore if man can do and know a thing it is doable and knowable in its essence. The business of science is to explore the secrets and laws of nature which were set by God. Islam has always encouraged man to contemplate, and explore, new horizons. Stem cell research is one of those new horizons, and Islam does not object to this exploration. All the discussion so far has indicated that stem cell research is permissible in Islam as long as it is carried out with the purpose of improving human health. This matter still, however, needs to be examined over and over again, and only after this has happened will it be possible for the final word to be said.

This paper should be regarded as a preliminary step, and as an istihsan due to maslahah of stem cell research. It is hope that the paper, by having thrown some light on the thinking 
and approaches of Islamic researchers and scholars, will help all scholars and researchers to reach a consensus on this controversial issue.

This paper was presented at the EUROSTEM Conference on Regulation and Legislation under conditions of Scientific Uncertainty in Bilbao, 2003 Mar 6-9.

Sahin Aksoy has a medical degree. After finishing his PhD on bioethics at the Centre for Social Ethics and Policy at the University of Manchester, in the United Kingdom, he was appointed as an associate professor and head of the department at Harran University, Faculty of Medicine, Department of Medical Ethics and History of Medicine, Sanliurfa, Turkey. He has published papers and made presentations on various topics in bioethics both nationally and internationally. He currently edits the Turkiye Klinikleri Journal of Medical Ethics, Law and Medicine and the Journal of the International Society of the History of Islamic Medicine. $\mathrm{He}$ is also the vice president of Asian Bioethics Association.

\section{REFERENCES}

1 Thomson J. Embryonic stem cell lines derived from human blastocysts. Science 1998;282:1145-7.

2 Pedersen R. Embryonic stem cells for medicine. Sci Am 1999;280:68-73.

3 Bruce DM. Stem cells, embryos and cloning-unravelling the ethics of a knotty debate. J Mol Biol 2002;319:917-25.

4 Weeramantry CG. Islamic jurisprudence: an international perspective. London: Macmillan, 1988.

5 Al-Ghazali AHM. Ihya' 'Ulum al-Din I. Istanbul: Bedir Publications, 1989 (In Turkish.).

6 Cooper DKC, Lanza RP. Xeno: the promise of transplanting animal organs into humans. Oxford: Oxford University Press, 2000.

7 Pearson H. Stem cell powers challenged. Nature 2002;15:734-5.

8 Harris J. The ethical use of human embryonic stem cells in research and therapy. In: Burley JC, Harris J, eds. A companion to genethics: philosophy and the genetic revolution. Oxford: Basil Blackwell, 2001.

9 McLaren A. Ethical and social considerations of stem cell research. Nature $2001 ; 14: 129-31$

10 Juengst $E$, Fossel $M$. The ethics of embryonic stem cells - now and forever, cells without end. JAMA 2000;284:3180-4.

11 Harris J. Should we experiment on embryos? In: Lee R, Morgan D, eds. Birthrights. London: Routledge, 1989:85-95.

12 Mahoney J. Bio-ethics and belief. London: Sheed \& Ward, 1984:67-9.

13 Albar MA. Human development, as revealed in the Holy Qur'an and Hadith Jeddah: Saudi Publishing House, 1992:57-62.

14 The Noble Qur'an. As-Sajdah 32, 8-9.

15 The Noble Qur'an. Al-Mu'minun 23,13-14

16 The Noble Qur'an. Nuh 71,14.

17 The Noble Qur'an. An-Nahl 16, 4.

18 The Noble Qur'an. Al-Qiyamah 75, 37-9.

19 The Noble Qur'an. At-Tariq 86, 6.

20 The Noble Qur'an. Al-Mursalat $77,20-1$.

21 The Noble Qur'an. Al-Insan 76, 2.
22 The Noble Qur'an. Al-Haii 22, 5

23 The Noble Qur'an. Al-'Alaq 96,1-2.

24 The Noble Qur'an. Ghafir 40, 67.

25 The Noble Qur'an. Az-Zumer 39, 6.

26 The Noble Qur'an. An-Naim 53, 45-6.

27 The Noble Qur'an. Fatir 35,11.

28 The Noble Qur'an. Al-'Imran 3, 6.

29 The Noble Qur'an. Al-Infitar 82, 68.

30 Al-Bukhari M. Al-Sahih, kitab bad' al-Khalq [vol 4]. Istanbul: Al-Maktaba alIslami, 1979:63.

31 Rispler-Chaim V. Islamic medical ethics in the twentieth century. Leiden: EJ Brill, 1993.

32 Ibn al-Zamlakani K. Al-Burhan al-Kashif an I'jaz al-Qur'an. (Discovering evidence for the inimitability of the Qur'an). Baghdad: Ani, 1964, 275 (In Arabic.)

33 Al-Sawi A. Atwar al-janin wa nafkh al-ruh (Prenatal development stages and ensoulment.) http://www.islamtoday.net/articles/show_articles_content. cfm?artid $=942 \&$ catid $=74$ (accessed 25 May 2004) (In Arabic.)

34 Abdul Rehman O. Does the Qur'an plagiarize ancient Greek embryology? http://www.aquaire.clara.co.uk/ (accessed 24 May 2004)

35 Aksoy S. A critical approach to the current understanding of Islamic scholars on using cadaver organs without prior permission. Bioethics 2001;15:461-72.

36 England MA. A colour atlas of life before birth. London: Wolfe Medical Publications, 1990.

37 Aksoy S. Can Islamic texts help to resolve the problem of the moral status of the prenate? Eubios Journal of Asian and International Bioethics 1998:8:76-9.

38 Omran AR. Family planning and the legacy of Islam. London: Routledge, 1992:190-3

39 Al-Bukhari M. Al-Sahih, kitab al-Tib [vol 7]. Istanbul: Al-Maktaba al-Islami, 1979:11

40 Ibn Hanbal A. Al-Musnad [vol 3]. Cairo: Dar al-Maarif, no date of publication:156.

41 Abu Dawud S. Al-Sunan, kitab al-Tib [vol 4]. Beirut: Dar al-Hadith, 1973:206.

42 Sachedina A. Islamic perspectives on research with human embryonic stem cells. In: National Bioethics Advisory Commission, eds. Ethical issues in human stem cell research [vol 3]. Religious perspectives. Rockville, MD: Government Printing Office, 2000:gl-g6.

43 Serour GI, Dickens BM. Assisted reproduction developments in the Islamic world. Int J Gynaecol Obstet 2001;74:187-93.

$44 \mathrm{http}: / / \mathrm{www}$.islam-nline.net/fatwaapplication/arabic/ display.asp?hFatwalD = 1471730 (accessed 25 Jan 2003)

45 Aksoy S, Elmali A. Four principles of bioethics as found in Islamic tradition. Med Law 2002;21:211-24.

46 http://www.islamset.com/bioethics/organ/salami.html\#2 (accessed 22 Jan 2003).

47 Human Genetics Advisory Commission and Human Fertilisation and Embryology Authority. Cloning issues in reproduction, science and medicine. London: Human Genetics Advisory Commission, 1998.

48 European Group on Ethics in Science and New Technologies. Ethical aspects of human stem cell research and use. Brussels: European Commission, 2000.

49 Robinson BA. Human cloning: comments by political groups, religious authorities http://www.religioustolerance.org (accessed 24 Feb 2003). 